\title{
Hubungan Kebiasaan Merokok dengan Waist to Hip Ratio (WHR) pada Nelayan di Kecamatan Koto Tangah Kota Padang
}

Fathiyyatul Khaira ${ }^{1}$, Delmi Sulastri ${ }^{2}$, Rima Semiarty ${ }^{3}$

\begin{abstract}
Abstrak
Nikotin pada rokok mempunyai efek anti estrogenik dan meningkatkan hormon kortisol yang mengakibatkan deposisi lemak ke abdomen maupun pengurangan massa otot panggul yang menyebabkan peningkatan Waist to Hip Ratio (WHR). Setiap kenaikan WHR sebesar 0,01 berhubungan dengan peningkatan risiko penyakit kardiovaskular. Tujuan penelitian ini adalah untuk mengetahui hubungan kebiasaan merokok dengan waist to hip ratio. Kebiasaan merokok dilihat dari status merokok, derajat merokok, jenis rokok, dan kadar nikotin dalam rokok. Data nama nelayan didapat dari Kelompok Usaha Bersama (KUB) nelayan di Kecamatan Koto Tangah. Dipilih 103 nelayan dengan metode simple random sampling. Data sekunder diperoleh dari wawancara dan pengukuran WHR. Data dianalisis menggunakan chi-square dan one way analysis of variance (ANOVA). Hasil uji statistik chi-square menunjukkan tidak ada hubungan bermakna antara status merokok $(p=0,156)$, derajat merokok $(p=0,261)$, dan jenis rokok $(p=1,000)$ dengan WHR. Kadar nikotin pada rokok $(p=0,013)$ memiliki hubungan bermakna dengan WHR. Hasil uji statistik One Way ANOVA menunjukkan tidak ada perbedaan bermakna WHR berdasarkan status merokok $(p=0,472)$ dan derajat merokok $(p=0,189)$. Berdasarkan jenis rokok yang dihisap $(p=0,025)$ menunjukkan perbedaan WHR yang bermakna. Disimpulkan kadar nikotin pada rokok dapat mempengaruhi WHR.
\end{abstract}

Kata kunci: status merokok, derajat merokok, jenis rokok, kadar nikotin, waist to hip ratio

\begin{abstract}
Nicotine in cigarette have anti estrogenic effect and increase the level of cortisol hormone that make smokers tend to have larger Waist to Hip Ratio (WHR) because of the deposition fat to abdomen and decrease muscle mass on the hip. Every 0,01 increase of WHR will increase cardiovascular risk. The objective of this study was to know the correlation between smoking behaviour with WHR. Smoking behaviour are smoking status, smoking degree, cigarette variance, and nicotine level in cigarette. Fisherman's name data get from Kelompok Usaha Bersama (KUB) of fisherman in Koto Tangah. From that data are choosed 103 fisherman with simple random sampling method. Secondary data get from quetionnaire and WHR measurement. Data analyze with chi-square and one way analysis of variance (ANOVA). Statistic result with chi-square showed that there are no significant correlation between smoking status $(p=0,156)$, smoking degree $(p=0,261)$, and cigarette variances $(p=1,000)$ with WHR. Otherwise nicotine level in cigarette $(p=0,013)$ has significant correlation with WHR. Statistic results with ANOVA showed that there are no significant differentiation of WHR by smoking status $(p=0,472)$ and smoking degree $(p=0,189)$. Otherwise cigarette variances $(p=0,025)$ have significant differentiation of WHR.
\end{abstract}

Keywords: smoking status, smoking degree, cigarette variances, nicotine level, waist to hip ratio

Affiliasi penulis: 1. Pendidikan Dokter FK UNAND (Fakultas Kedokteran Universitas Andalas Padang), 2. Bagian Gizi FK UNAND,

3. Bagian Kesehatan Masyarakat FK UNAND

Korespondensi: FK Unand, Jl. Perintis Kemerdekaan, Padang.

Email: fathiyyatul.khaira@gmail.com Telp: 085278410033

\section{PENDAHULUAN}

Waist to Hip Ratio (WHR) atau rasio lingkar pinggang dan panggul diyakini sebagai prediktor yang baik untuk menilai risiko penyakit kardiovaskular. 
Setiap kenaikan WHR sebesar 0,01 berhubungan dengan peningkatan risiko penyakit kardiovaskular. ${ }^{1}$ Beberapa hal yang mempengaruhi WHR adalah hormon seks, umur, status reproduksi, etnis, dan perilaku buruk seperti merokok dan konsumsi alkohol. ${ }^{2-4}$

Kebiasaan merokok merupakan masalah internasional yang belum teratasi. Penelitian World Health Organization (WHO) dalam Me'ndez et al menunjukkan pada tahun 2010 diperkirakan 24\% dari jumlah penduduk dunia mempunyai kebiasaan merokok atau sekitar 794 juta jiwa. Empat negara dengan total perokok terbanyak adalah China (28\%), India (11\%), Indonesia (4,8\%), dan USA $(4,7 \%){ }^{5}$

Berdasarkan data Riskesdas 2010, Sumatera Barat termasuk dalam lima provinsi tertinggi dalam prevalensi merokok tiap hari, yaitu $33,1 \%$ dan prevalensi tertinggi perokok berdasarkan pekerjaan adalah petani/nelayan/buruh yaitu $50,3 \%{ }^{6}{ }^{6}$ Tujuh kecamatan di Sumatera barat yang berlokasi di tepi pantai, Kecamatan Koto Tangah memiliki jumlah nelayan terbanyak yaitu 443 nelayan. $^{7}$

Hubungan merokok dengan obesitas sentral merupakan sebuah paradoks. Di satu sisi perokok mempunyai BMI yang lebih rendah daripada orang yang tidak merokok. ${ }^{8}$ Di sisi lain, pada perokok ditemukan WHR yang lebih tinggi daripada nonperokok, dengan kata lain perokok cenderung obesitas sentral atau obesitas abdominal. ${ }^{2}$ Peningkatan WHR pada perokok disebabkan oleh nikotin pada rokok dapat meningkatkan WHRmelalui efek anti estrogenik dan peningkatan hormon kortisol. ${ }^{9}$ Peningkatan WHR ini sesuai dengan jumlah rokok yang dihisap (dose dependent). ${ }^{2}$

Berdasarkan latar belakang di atas, perlu diketahui hubungan kebiasaan merokok dengan Waist to Hip Ratio pada nelayan di Kecamatan Koto Tangah, Kota Padang.

\section{METODE}

Penelitian ini menggunakan desain cross sectional dimana kebiasaan merokok sebagai faktor risiko dan WHR sebagai efek yang diteliti. Populasi penelitian ini adalah semua nelayan yang tergabung dalam Kelompok Usaha Bersama (KUB) nelayan di Kecamatan Koto Tangah.Sampel merupakan bagian dari populasi yang diteliti jumlahnya dan mempunyai kriteria inklusi dan kriteria eksklusi.

Data primer didapat dengan cara wawancara langsung menggunakan kuesioner terhadap nelayan di Kecamatan Koto Tangah, Padang mengenai karakteristik pasien (umur dan tingkat pendidikan) serta kebiasaan merokok disesuaikan dengan smoking questionnaire yang dipakai pada proyek WHO MONICA. Pengukuran rasio lingkar pinggang dan panggul (WHR) pada subjek penelitian dilakukan oleh peneliti dengan mengukur lingkar pinggang dan panggul subjek penelitian.

Lingkar pinggang diukur dengan cara responden berdiri tegak, posisi tangan di samping, dan kaki dirapatkan. Responden diminta untuk mengangkat bajunya sedikit ke atas dan menghembuskan napas secara perlahan untuk mencegah kontraksi otot abdomen saat menahan napas.Pita ukur tidak menekan kulit dan nilai lingkar pinggang diambil dalam milimeter terdekat.

Posisi responden pada saat pengukuran lingkar panggul sama dengan pengukuran lingkar pinggang akan tetapi pengukuran dilakukan pada lingkaran terluas dari panggul responden dengan tetap memakai celana dan dinilai pada milimeter terdekat.

HASIL

\section{Karakteristik Responden}

Dari 103 responden dapat dilihat bahwa hampir seluruh responden termasuk kelompok usia produktif. Sebagian besar responden memiliki tingkat pendidikan yang rendah.Hampir seluruh responden merupakan perokok saat ini.

Tabel 1. Karakteristik responden

\begin{tabular}{lcc}
\hline \multicolumn{1}{c}{ Variabel } & f & $\%$ \\
\hline Kelompok Usia & 100 & $97,1 \%$ \\
$\begin{array}{l}\text { Produktif } \\
\text { Tidak Produktif }\end{array}$ & 3 & $2,9 \%$ \\
\hline Tingkat Pendidikan & & \\
Rendah & 84 & $81,6 \%$ \\
Sedang & 17 & $16,5 \%$ \\
Tinggi & 2 & $1,9 \%$ \\
\hline Status Merokok & & \\
Perokok Saat Ini & 98 & $95,1 \%$ \\
Mantan Perokok & 4 & $3,9 \%$ \\
Tidak Pernah Merokok & 1 & $1 \%$ \\
\hline
\end{tabular}


Hubungan Kebiasaan Merokok dengan Waist to Hip Ratio

Secara klinis, WHR dipakai untuk menentukan seseorang menderita obesitas sentral atau tidak. Tabel 2 menjelaskan hubungan kebiasaan merokok dengan terjadinya obesitas sentral.

Tabel 2. Hubungan kebiasaan merokok dengan WHR

\begin{tabular}{|c|c|c|c|c|c|}
\hline \multirow{3}{*}{ Variabel } & \multicolumn{4}{|c|}{ Waist to Hip Ratio } & \multirow{3}{*}{$\mathbf{p}$} \\
\hline & \multicolumn{2}{|c|}{$\begin{array}{c}\text { Obesitas } \\
\text { Sentral }\end{array}$} & \multicolumn{2}{|c|}{$\begin{array}{c}\text { Tidak } \\
\text { Obesitas } \\
\text { Sentral }\end{array}$} & \\
\hline & $f$ & $\%$ & $f$ & $\%$ & \\
\hline \multicolumn{6}{|l|}{ Status } \\
\hline \multicolumn{6}{|l|}{ Merokok } \\
\hline Perokok & 38 & $38,8 \%$ & 60 & $61,2 \%$ & \multirow{2}{*}{0,156} \\
\hline Perokok & 4 & $80,0 \%$ & 1 & $20,0 \%$ & \\
\hline \multicolumn{6}{|l|}{ Derajat } \\
\hline \multicolumn{6}{|l|}{ Merokok } \\
\hline Ringan & 3 & $20,0 \%$ & 12 & $80,0 \%$ & \multirow{3}{*}{0,261} \\
\hline Sedang & 21 & $41,2 \%$ & 30 & $58,8 \%$ & \\
\hline Berat & 14 & $43,8 \%$ & 18 & $56,2 \%$ & \\
\hline \multicolumn{6}{|l|}{ Jenis } \\
\hline \multicolumn{6}{|l|}{ Rokok } \\
\hline $\begin{array}{l}\text { Rokok } \\
\text { Kretek }\end{array}$ & 36 & $38,7 \%$ & 57 & $61,3 \%$ & \multirow[b]{2}{*}{1,000} \\
\hline $\begin{array}{l}\text { Rokok Putih } \\
\text { dan lainnya }\end{array}$ & 2 & $40,0 \%$ & 3 & $60,0 \%$ & \\
\hline \multicolumn{6}{|l|}{ Kandungan } \\
\hline \multicolumn{6}{|l|}{ Nikotin } \\
\hline Rendah & 12 & $26,1 \%$ & 34 & $73,9 \%$ & \multirow{2}{*}{0,013} \\
\hline Regular & 24 & $51,1 \%$ & 23 & $48,9 \%$ & \\
\hline
\end{tabular}

Tabel 2 dapat dilihat 98 perokok saat ini, persentase responden yang menghisap rokok kretek dengan kandungan nikotin regular (>1,5mg per batang rokok) yang mengalami obesitas sentral lebih tinggi $(51,1 \%)$ dibandingkan dengan yang tidak mengalami obesitas sentral (48,9\%). Dari hasil uji statistik terdapat hubungan kandungan nikotin dalam rokok yang dihisap dengan WHR.

\section{Perbedaan rerata WHR berdasarkan kebiasaan merokok}

Perbedaan rerata WHR berdasarkan status merokok, derajat merokok, dan jenis rokok digunakan uji one way ANOVA yang dapat dilihat pada Tabel 3.
Tabel 3. Perbedaan rerata WHR berdasarkan kebiasaan merokok

\begin{tabular}{|c|c|c|c|c|c|}
\hline Variabel & $f$ & $\overline{\mathbf{x}} \pm \mathbf{S D}$ & Min & Maks & p \\
\hline \multicolumn{6}{|l|}{ Status } \\
\hline \multicolumn{6}{|l|}{ Merokok } \\
\hline \multicolumn{6}{|l|}{ Perokok saat ini } \\
\hline Mantan & 98 & $0,884 \pm 0,05$ & 0,76 & 0,99 & \multirow{4}{*}{0,472} \\
\hline Perokok & 4 & $0,908 \pm 0,07$ & 0,81 & 0,95 & \\
\hline Tidak Pernah & 1 & 0,93 & 0,93 & 0,95 & \\
\hline \multicolumn{5}{|l|}{ Merokok } & \\
\hline \multicolumn{6}{|l|}{ Derajat } \\
\hline \multicolumn{6}{|l|}{ Merokok } \\
\hline Ringan & 15 & $0,864 \pm 0,06$ & 0,78 & 0,99 & \multirow{3}{*}{0,189} \\
\hline Sedang & 51 & $0,883 \pm 0,05$ & 0,76 & 0,98 & \\
\hline Berat & 32 & $0,894 \pm 0,05$ & 0,79 & 0,99 & \\
\hline \multicolumn{6}{|l|}{ Jenis Rokok } \\
\hline \multicolumn{6}{|l|}{ Rokok Kretek } \\
\hline $\begin{array}{l}\text { - Low Tar and } \\
\text { Nicotine }\end{array}$ & 46 & $0,8683 \pm 0,05$ & 0,76 & 0,99 & \\
\hline $\begin{array}{l}\text { - Regular Tar } \\
\text { and Nicotine }\end{array}$ & 47 & $0,9002 \pm 0,05$ & 0,79 & 0,99 & 0,025 \\
\hline Rokok Putih & 4 & $0,8650 \pm 0,05$ & 0,81 & 0,91 & \\
\hline Lainnnya & 1 & 0,87 & 0,87 & 0,87 & \\
\hline
\end{tabular}

Tabel 3 memperlihatkan WHR perokok yang mengkonsumsi rokok kretek dengan kandungan nikotin yang rendah ( $<1,1 \mathrm{mg}$ per batang rokok) memiliki WHR yang lebih rendah dibandingkan dengan perokok yang mengkonsumsi rokok kretek regular dengan nikotin yang lebih tinggi (>1,5 mg per batang rokok).

\section{PEMBAHASAN}

\section{Hubungan Status Merokok dengan WHR}

Sebanyak 98 responden yang diteliti yaitu nelayan Kecamatan Koto Tangah, didapatkan 1\% responden yang tidak pernah merokok, 3,9\% responden merupakan mantan perokok, dan 95,1\% responden merupakan perokok saat ini. Prevalensi responden yang didapat berbeda dari hasil penelitian Clair et al dimana prevalensi yang ditemukan hampir sama banyak yaitu $32,1 \%$ responden yang tidak pernah merokok, 38,5\% responden merupakan mantan perokok, dan 29,4\% responden perokok. ${ }^{9}$

Perbedaan ini dikarenakan peneliti mengambil sampel di daerah nelayan dimana menurut Riskesdas 2010, prevalensi perokok memang ditemukan tinggi pada kelompok pekerjaaan tersebut. ${ }^{6}$ Sedangkan Clair et al meneliti populasi usia 35-75 tahun di kota Lausanne, Switzerland. ${ }^{9}$ 
Hasil analisis menggunakan chi-square tidak ditemukan hubungan antara status merokok dengan Waist to Hip Ratio. Hal ini mungkin karena kurangnya responden yang mantan perokok dan tidak pernah merokok. Tidak ada penelitian yang mendukung penelitian ini, tetapi pada perokok ditemukan WHR yang lebih tinggi daripada non-perokok, dengan kata lain perokok cenderung obesitas sentral. ${ }^{2}$

Hasil analisis menggunakan one way ANOVA menunjukkan tidak terdapat perbedaan bermakna pada WHR berdasarkan status merokok. Namun berbeda dengan hasil penelitian Canoy et al. ${ }^{10}$ yang menunjukkan $\mathrm{P}<0,01$ dan Akbartabartoori et al. ${ }^{11}$ dengan $\mathrm{P}<0,001$ yang berarti perbedaan bermakna pada WHR berdasarkan status merokok.

Perbedaan ini mungkin dikarenakan oleh faktor-faktor lain yang mempengaruhi WHR seperti aktivitas fisik nelayan yang berat. Sedangkan subjek penelitian Canoy et al adalah 21,828 laki-laki dan perempuan berusia 45-79 tahun yang bertempat tinggal di Norfolk, Inggris dimana 37\% laki-laki yang merupakan perokok saat ini memiliki aktivitas fisik yang kurang (sedentary lifestyle). ${ }^{10}$

\section{Hubungan Derajat Merokok dengan WHR}

Hasil analisis menggunakan chi-square tidak ditemukan hubungan antara derajat merokok dengan Waist To Hip Ratio. Dari hasil analisis menggunakan one way ANOVA tidak ditemukan perbedaan yang bermakna antara derajat merokok dengan WHR.Namun berdasarkan penelitian Canoy et al didapatkan $\mathrm{P}<0,001$ yaitu ada perbedaan WHR antara orang yang tidak pernah merokok dengan perokok saat ini yang mengkonsumsi rokok <10 pack-years dan $\geq 10$ pack-years. ${ }^{10}$

Ada hubungan dose-response jumlah rokok yang dihisap dan lama merokok (pack-years) dengan WHR perokok. ${ }^{2}$ Klasifikasi yang berbeda mengenai derajat merokok mungkin menyebabkan perbedaan dalam hasil penelitian ini.Dalam penelitian ini derajat merokok ditentukan berdasarkan indeks brinkman yaitu jumlah batang rokok yang dihisap dalam sehari dikali dengan lama merokok dalam tahun. ${ }^{12}$ Canoy et al membagi derajat merokok menjadi <10pack-years dan $\geq 10$ pack-years. ${ }^{10}$
Hasil penelitian ini ditemukan sedikit perbedaan antara derajat merokok dan WHR. WHR perokok derajat sedang lebih besar 0,018 daripada perokok derajat ringan sedangkan WHR perokok derajat berat 0,012 lebih besar daripada perokok derajat sedang.

Penelitian Canoy et almenyatakan bahwa pada perokok yang telah merokok <10pack-years memiliki WHR yang meningkat sebesar 0,007 daripada orang yang tidak pernah merokok sedangkan perokok yang telah merokok $\geq 10$ pack-years mengalami peningkatan WHR sebesar 0,015 daripada orang yang tidak pernah merokok.Hal diatas dapat membuktikan adanya hubungan dose-response merokok dengan peningkatan WHR. ${ }^{10}$

\section{Hubungan Jenis Rokok dengan WHR}

Hasil uji chi-square tidak ditemukan hubungan antara jenis rokok yang dihisap dengan waist to hip ratio. Hal ini dikarenakan kurangnya responden yang merokok dengan rokok putih maupun yang lainnya.

\section{Hubungan Kandungan Nikotin pada Rokok dengan WHR}

Pada umumnya responden menghisap rokok kretek sehingga dapat dibedakan berdasarkan kandungan nikotinnya. Dari hasil analisis menggunakan chi square ditemukan hubungan antara kandungan nikotin dalam rokok dengan WHR. Hasil analisis menggunakan one way ANOVA juga didapat perbedaan WHR yang signifikan antara orang yang mengkonsumsi rokok dengan kandungan nikotin rendah (<1,1 mg per batang rokok) dan kandungan nikotin regular ( $>1,5 \mathrm{mg}$ per batang rokok). Namun tidak ditemukan data untuk mendukung hasil penelitian ini. Nikotin pada rokok mempunyai efek antiestrogenik dan peningkatan kandungan hormon stress seperti kortisol. ${ }^{9}$ Efek anti-estrogenik berpengaruh terhadap ketidakseimbangan aktivitas estrogen dan androgen pada perokok. ${ }^{10}$ Kandungan kortisol yang berlebihan mempengaruhi distribusi jaringan adiposa yang terkumpul di sentral tubuh dan menyebabkan obesitas. ${ }^{13}$ Sehingga dapat disimpulkan semakin lama seseorang merokok dan semakin banyak jumlah rokok yang dihisap, tentu semakin banyak pula nikotin yang dihisap yang akan berpengaruh pada WHR. 


\section{KESIMPULAN}

Tidak ada hubungan bermakna antara status merokok, derajat merokok, dan jenis rokok dengan WHR. Sedangkan kadar nikotin pada rokok memiliki hubungan bermakna dengan WHR. Hasil uji statistik One Way ANOVA menunjukkan tidak ada perbedaan bermakna WHR berdasarkan status merokok dan derajat merokok.Sedangkan berdasarkan jenis rokok yang dihisap menunjukkan perbedaan WHR yang bermakna.

\section{DAFTAR PUSTAKA}

1. de Koning L, Anwar T. Merchant, Janice P, Sonia $S$, Anand. Waist circumference and waist-to-hip ratio as predictors of cardiovascular events: metaregression analysis of prospective studies. European Heart Journal. 2007;28:850-6.

2. Chiolero A, Faeh D, Paccaud F, Cornuz J. Consequences of smoking for body weight, body fat distribution, and insulin resistance. AJCN. 2008;87(4):801-9.

3. World Health Organization. Waist circumference and waist-hip ratio : report of a WHO expert consultation. Geneva: WHO; 2008.

4. Laws A, Terry RB, Barrett-Connor E. Behavioral covariates of waist-to-hip ratio in rancho bernardo. AJPH. 1990;80(11):1358-62.

5. Me'ndez, D., Alshanqeety $O$, Kenneth EW. The potential impact of smoking control policies on future global smoking trends. BMJ. 2012;22:46-51.

6. Departemen Kesehatan RI. Riset Kesehatan Dasar 2010. Jakarta: Badan Litbangkes; 2010.
7. Badan Perencanaan Pembangunan Daerah. Kerangka acuan kerja penyusunan strategi penanggulangan kemiskinan kawasan pesisir bidang sosial budaya. Padang; 2013.

8. Molarius AJC, Seidell K, Kuulasmaa, Dobson AJ, Sans S. Smoking and relative body weight: an international perspective from the WHO MONICA Project, Journal of Epidemiology and Community Health. 1997;51:252-60.

9. Clair C, Chiolero A, Faeh D, Cornuz J, MarquesVidal P, Paccaud F, et al. Dose-dependent positive association between cigarette smoking, abdominal obesity and body fat: cross-sectional data from a population-based survey. BMC Public Health Prepublication. 2011.

10. Canoy D, Wareham N, Luben R, Welch A, Bingham S, Day N, et al. Cigarette Smoking and fat distribution in 21,828 British men and women: a population-based study. Obesity Research. 2005;13(8):1466-75.

11. Akbartabartoori M, Lean MEJ, Hankey CR. Relationships between cigarette smoking, body size and body shape, International Journal of Obesity. 2005;29:236-43.

12. Perhimpunan Dokter Paru Indonesia. Penyakit paru obstruktif kronik (PPOK): diagnosis dan penatalaksanaan di Indonesia. Jakarta; 2011.

13. Schteingart DE. Gangguan hipersekresi adrenal. Dalam : Hartanto et al, editor (penyunting). Patofisiologi Konsep Klinis Proses-Proses Penyakit Volume:2. Edisi ke-6. Jakarta: EGC; 2003. hlm.1239 